Published in final edited form as:

Clin Gastroenterol Hepatol. 2007 November ; 5(11): 1282-1245.

\title{
Adult Autoimmune Enteropathy: Mayo Clinic Rochester Experience
}

\author{
Salma Akram, M.D. ${ }^{1}$, Joseph A. Murray, M.D. ${ }^{1}$, Darrell S. Pardi, M.D. ${ }^{1}$, Glenn L. Alexander, \\ M.D. ${ }^{1}$, John A. Schaffner, M.D. ${ }^{1}$, Pierre A. Russo, M.D. ${ }^{2}$, and Susan C. Abraham, M.D. ${ }^{3}$ \\ 1 Division of Gastroenterology and Hepatology, Department of Internal Medicine, Mayo Clinic, Rochester, \\ $M N$ \\ 2 Department of Pathology and Laboratory Medicine, The Children's Hospital of Philadelphia, Philadelphia, \\ Pennsylvania
}

3 Division of Anatomic Pathology, Department of Pathology, Mayo Clinic College of Medicine, Rochester, Minnesota

\section{Abstract}

Purpose-Autoimmune enteropathy is a rare cause of intractable diarrhea associated with circulating gut autoantibodies and a predisposition to autoimmunity. It is rarely observed in adults with only eleven cases reported to date.

Methods-Fifteen adults with autoimmune enteropathy were identified at the Mayo Clinic, Rochester, from May 2001 to June 2006. The demographic, clinical and treatment data were abstracted from their records.

Results-The study population was $87 \%$ Caucasian, $47 \%$ females, with median age of 55 years (interquartile range: 42 to 67 years). All patients had diarrhea, weight loss and malnutrition. Celiac disease was excluded by lack of response to gluten free diet or absence of the celiac disease susceptibility HLA genotypes. Fourteen patients were tested for gut epithelial cell antibodies and 93\% were positive for anti-enterocyte and/or anti-goblet cell antibodies. Predisposition to autoimmune diseases was noted in $80 \%$, as indicated by a variety of circulating autoantibodies. Small intestinal histopathologic findings included subtotal villous atrophy and lymphoplasmacytic infiltration in the lamina propria with relatively few surface intraepithelial lymphocytes. T-cell receptor gene rearrangement studies were negative in all cases. Immunosuppressive therapy was required in $93 \%$ cases. Clinical improvement was noted in $60 \%$ after $1-8$ weeks of steroid therapy.

Conclusion-Autoimmune enteropathy is a heterogeneous disease and should be considered in the differential diagnosis of malabsorption and small bowel villous atrophy. The presence of gut epithelial cell antibodies can help confirm the diagnosis. No single agent is unequivocally effective in inducing remission, and immunosuppressive therapy is required in most cases.

Corresponding Author: Joseph A. Murray, MD, Miles and Shirley Fiterman Center for Digestive Diseases, 200 First Street SW, Rochester, Minnesota 55905, Phone: (507) 284-2631, Fax: (507) -266-9081, e-mail: murray.joseph@ mayo.edu.

Presented at American College of Gastroenterology $70^{\text {th }}$ Annual Scientific Meeting November 2005, Honolulu, Hawaii and published in abstract form (American Journal of Gastroenterology. 2005; 100(9): S632).

All Authors: There is no conflict of interest to disclose.

Publisher's Disclaimer: This is a PDF file of an unedited manuscript that has been accepted for publication. As a service to our customers we are providing this early version of the manuscript. The manuscript will undergo copyediting, typesetting, and review of the resulting proof before it is published in its final citable form. Please note that during the production process errors may be discovered which could affect the content, and all legal disclaimers that apply to the journal pertain. 


\section{Keywords}

Autoimmune enteropathy; intractable diarrhea; anti-enterocyte antibodies; anti-goblet cell antibodies; malabsorption; refractory sprue; immunosuppressive agent

\section{BACKGROUND}

Autoimmune enteropathy (AIE) is a rare cause of intractable diarrhea associated with circulating gut autoantibodies and a predisposition to autoimmunity. The term AIE was first coined by Unsworth and Walker-Smith, two pediatric gastroenterologists from St.

Bartholomew's Hospital in London, in $1982{ }^{1}$ after their experience with a 15 month old child who presented with protracted diarrhea, weight loss and vomiting. There was evidence of villous atrophy which did not respond to dietary exclusion of gluten, cow's milk, eggs or to 8 weeks of complete bowel rest with intravenous alimentation. The child was also positive for IgG anti-enterocyte antibodies which disappeared after treatment with cyclophosphamide, though the mucosal abnormalities persisted to some degree ${ }^{1}$. The diagnostic criteria for AIE, proposed by Unsworth and Walker-Smith, include: (1) severe villous atrophy not responding to any dietary restriction; (2) circulating gut autoantibodies and/or associated autoimmune conditions, and (3) lack of severe immunodeficiency ${ }^{2}$. Although it is primarily considered to be a disease of children, adult-onset AIE has recently been described, with a total of eleven cases reported to date. The pathophysiology of AIE is not completely understood but the available evidence suggests a hyperactive immune state due to a defect in regulatory T-cell homeostasis ${ }^{3}$. Autoimmune enteropathy must be distinguished from refractory sprue, which is a form of celiac disease no longer responsive to a gluten free diet ${ }^{4}$. Due to the rarity of the disease, there is scarce data regarding the epidemiology, natural course and therapeutic options for AIE. Thus, treatment decisions are primarily guided by anecdotal experience. Many treatments, including corticosteroids, immunosuppressive drugs like azathioprine, cyclophosphamide, tacrolimus, cyclosporine and infliximab, have been used with varying success ${ }^{5-9}$. In the present study, we sought to describe the clinical features, treatment and outcome of adult patients with AIE seen at our institution over the past five years.

\section{METHODS}

All patients seen at Mayo Clinic, Rochester from May, 2001 to June, 2006 with a diagnosis of adult-onset AIE were identified either retrospectively through the diagnostic index and Department of Pathology database, or prospectively through our outpatient clinics. AIE was defined as adult onset protracted diarrhea not responsive to any dietary exclusion and associated with intestinal villous atrophy, circulating gut autoantibodies and/or predisposition to autoimmunity. All pathology slides, except one, were reviewed by a single Mayo GI pathologist (SCA). Serological testing and indirect immunofluorescence staining for the gut epithelial cell antibodies (GECA), namely anti-enterocyte (AE) and anti-goblet (AG) were performed at The Children's Hospital of Philadelphia. Demographic, clinical and treatment data were abstracted from the medical records and outcome data was supplemented by follow-up telephone interviews. The study was approved by Mayo Internal Review Board.

\section{RESULTS \\ Clinical Features}

We identified 15 cases of AIE (Tables 1 and 2) during the study period, with a median age of 55 years (interquartile range: $42-67$ years) at diagnosis. The majority of patients, $87 \%$, were Caucasians with eight males and seven females. All patients had protracted chronic diarrhea, weight loss and malnutrition. The median duration of symptoms prior to the diagnosis was 1.5 
years (interquartile range: $1-4.5$ years). Seven patients (47\%) required parenteral nutritional support because of significant weight loss. Celiac disease (CD) was excluded in 13 patients (87\%) by lack of any response to a gluten free diet (GFD) and absence of the CD susceptibility HLA genotypes. The other 2 patients (13\%) fulfilled criteria for refractory sprue. Both the patients had CD associated HLA genotype, positive IgA tissue transglutaminase antibodies (tTG), and histologic picture compatible with sprue in one case and features of both AIE and sprue in the other case. Both these patients were unresponsive to strict GFD and tested positive for anti-enterocyte antibodies. T-cell receptor gene rearrangement studies, by PCR amplification ruled out any clonal proliferation in both the cases. Fourteen patients were tested for gut epithelial cell autoantibodies (GECA) (Table 3); 13 (93\%) were positive for antienterocyte (Figure 1) and/or anti-goblet cell antibodies (Figure 2), including two who fulfilled criteria for refractory sprue. Abdominal CT was unremarkable in all cases except prominent mesenteric lymph nodes in 6 cases (40\%). The average stool output, estimated at the time of diagnosis in 9 cases (60\%), was $4256 \mathrm{~g} /$ day, with an average fecal fat content of $60 \mathrm{~g} /$ day on a high fat diet $(\geq 100 \mathrm{~g} / \mathrm{d})$. Additional laboratory abnormalities included elevated hepatic transaminases ( 2 to 5 times upper limit of normal) in $10(67 \%)$, fat-soluble vitamin deficiencies in $9(60 \%)$, elevated IgA tTG antibodies in $5(33 \%)$, and mild immunoglobulin deficiencies either IgG subtype, IgM or IgA in 5 patients (33\%). Another 2 patients (18\%) had concurrent common variable immunodeficiency (CVID). A predisposition to autoimmunity was noted in 12 patients $(80 \%)$, as indicated by a variety of circulating autoantibodies and associated autoimmune disorders (Table 3).

Initial esophagogastroduodenoscopy (EGD) was grossly abnormal in 8 patients (53\%) showing duodenal scalloping, fissuring, mosaic pattern and villous atrophy. Capsule enteroscopy (CE) was performed in 7 patients (47\%). Capsule failed to leave the stomach in one case and in all others CE showed abnormal small bowel (SB). In five cases (71\%) CE changes of fissuring, scalloping and mosaic pattern were restricted to the proximal SB. One case had aphthous ulceration in the mid-SB and edema of the distal SB.

\section{Histopathology}

Small bowel biopsies were available for review (by SCA) in 14 of 15 cases. In 8 patients (57\%) (all but one with anti-enterocyte and/or anti-goblet cell antibodies), the biopsies demonstrated classic histopathologic features of AIE as previously described in children including increased mononuclear inflammation in the lamina propria, lymphocytic infiltration into deep crypt epithelium with a relative paucity of surface lymphocytosis $(<40$ lymphocytes per 100 epithelial cells), and increased numbers of crypt apoptotic bodies (Figure 3). In all patients except one, the lamina propria mononuclear infiltrates were composed of both plasma cells and lymphocytes; one patient with CVID lacked mucosal plasma cells but had prominent lymphocytic lamina propria infiltrates. Villous blunting was evident in all biopsies, ranging from mild (villous: crypt ratio $1: 1 ; n=2)$, to moderate $(n=4)$, to severe (total or near-total villous atrophy; $\mathrm{n}=2$ ). In 5 of these cases, there was neutrophilic cryptitis and villitis. Goblet cells were absent from the epithelium in 6 cases and Paneth cells in 3 cases. Many patients had evidence for an autoimmune process involving the entire gastrointestinal tract (Figure 4). Concomitant colonic biopsies were taken in 5 of 8 patients; only one was normal, whereas the others all demonstrated histologic abnormalities identical to those seen in the small bowel. Gastric biopsies were taken in 3 patients and revealed autoimmune atrophic gastritis in two cases and normal histology in one.

In 3 patients (21\%), small bowel biopsies demonstrated histopathologic features of both AIE and celiac disease (Figure 5). All showed near-total villous atrophy with surface intra-epithelial lymphocytosis (IEL) ranging from 50 lymphocytes per 100 epithelial cells to $\geq 100$ lymphocytes per 100 epithelial cells. All had neutrophilic cryptitis, increased numbers of deep 
crypt apoptoses, and deep cryptal lymphocytosis. In one patient, there was absence of goblet cells. This group of patients included 2 with positive anti-enterocyte antibodies (GECA were not tested in the other), 2 with positive gluten-sensitivity antibodies, and one with celiac disease-associated HLA type (DQ2). Concomitant colon biopsies were obtained in 2 patients; one was normal, and the other demonstrated mild lymphocytic colitis (20 lymphocytes/100 epithelial cells). Gastric fundal biopsy obtained in one patient revealed autoimmune atrophic gastritis.

In 3 patients (21\%) with positive GECA (anti-enterocyte antibodies in 2 cases and anti-goblet cell antibody in the other), small bowel biopsies lacked classic features of AIE and instead revealed sprue-like changes. There was surface intra-epithelial lymphocytosis ranging from 50 lymphocytes/ 100 epithelial cells to $\geq 100$ lymphocytes/100 epithelial cells. Villous blunting was mild in one patient and near-total in the other two. One patient had CVID and showed an absence of plasma cells in the lamina propria. None of the biopsies had neutrophilic inflammation or absence of goblet cells. Gluten-sensitivity antibodies were demonstrated in 2 of these 3 patients, and one also had the celiac-associated HLA type DQ2.

The remaining patient, whose small bowel biopsy had previously been reviewed by another Mayo GI pathologist and was not available for review by SCA, showed total villous atrophy, crypt hyperplasia, increased IEL (60-80 lymphocytes per 100 epithelial cells) and chronic inflammation suggestive of celiac sprue. This patient had both positive anti-enterocyte antibodies (IgG) and positive gluten-sensitivity antibodies (tTG IgA, anti-gliadin IgG and IgA). Celiac-associated HLA type, however, was negative.

\section{Treatment and Outcomes}

Fourteen patients (93\%), including two with CVID that failed prior treatment with IV immunoglobulins, received immunosuppressive therapy (Table 4); prednisone alone was used in 4, prednisone followed by budesonide in 2, prednisone followed by azathioprine or 6mercaptopurine in 3 , prednisone followed by budesonide and azathioprine in one, budesonide followed by prednisone in one, budesonide followed by azathioprine in one, and prednisone followed by either 6-mercaptopurine (6-MP) or azathioprine with infliximab in 2 patients. The remaining one patient received metronidazole $500 \mathrm{mg}$ orally three times a day for 4 weeks and diphenoxylate without benefit.

Overall, 9 patients (60\%) responded clinically with near/complete resolution of diarrhea, 3 patients (20\%) had a partial response with less than 50\% reduction in bowel frequency, and 3 patients (20\%) failed to respond. Follow-up small bowel endoscopic biopsies were available in six of the nine responders and showed normal appearing small bowel mucosa with preserved villous architecture and without significant inflammatory infiltrate. Persistent villous atrophy was noted in follow-up endoscopic biopsies from those with partial clinical response. Rapid clinical response to high dose steroids (defined as steroids $\geq 40 \mathrm{mg} /$ day) was noted in two cases. However, 3 to 11 months later both these patients required additional immunomodulatory therapy to maintain clinical remission. One patient responded quickly to prednisone $10 \mathrm{mg} /$ day and remained in remission on prednisone $5 \mathrm{mg} /$ day during 14 months of follow-up. One patient, refractory to intravenous high dose methylprednisolone and 6-MP for six months, had a dramatic response to infliximab $(5 \mathrm{mg} / \mathrm{kg})$ within one week of the second dose. Infliximab was given as an induction dose at $0,2,6$ weeks followed by a maintenance dose every 8 weeks. The patient first experienced resolution of abdominal pain, followed by steady weight gain, then improvement of diarrhea, and finally discontinuation of parenteral nutritional support within six weeks of first dose. The other five responders achieved remission on $20-60 \mathrm{mg} /$ day prednisone in $4-8$ weeks. Two of these were later switched to budesonide 6-12 mg/day for maintenance. Azathioprine $2 \mathrm{mg} / \mathrm{kg}$ /day was added in one of these two cases. Three partial responders had a waxing and waning course despite immunomodulator therapy. 


\section{Follow-up}

Follow-up of more than one year was available in 13 patients $(87 \%)$. The median length of follow-up from the onset of symptoms to the date of last clinical contact was 2 years (interquartile range: $1-4.8$ years). One patient died six months after the onset of symptoms from overwhelming septicemia complicating unremitting underlying disease. There were two thromboembolic events, without any known risk factors, including sagittal venous sinus thrombosis and deep venous thrombosis with pulmonary embolism 6-8 months after the onset of symptoms.

\section{DISCUSSION}

AIE is defined as a condition with adult-onset chronic diarrhea, malabsorption, complete lack of response to GFD or other dietary exclusions with specific small intestinal histologic features and is usually characterized by the presence of circulating GECA. Based on our experience a proposed diagnostic criteria for AIE is listed in Table 6.

The current study represents the largest series of adult patients reported to date with the diagnosis of AIE. All these cases share a constellation of clinical features which are similar to what has previously been reported in children $1,10-13$ and more recently in adults $6,14-20$ (Table 5).

AIE appears to represent a spectrum of generalized immune dysregulation. One third of the patients in our series showed evidence of autoimmune gastroenterocolitis. Similar findings have been reported in children ${ }^{13}$ and two adults with AIE ${ }^{14,18}$. In addition, a high number of patients (80\%) in the current study had an associated autoimmune disorder or circulating autoantibodies. A predisposition to other autoimmune diseases has been reported in other cases of $\operatorname{AIE} 13,17,21$. Extensive intestinal and extra-intestinal clinical involvement with a variety of associated antibodies supports the hypothesis that AIE represents one feature of a generalized hyperactive immune state, with an apparent loss of proper controls 22 .

Pathophysiology of AIE is not known but deficiency or dysfunction of $\mathrm{CD} 25^{+} \mathrm{CD} 4^{+}$regulatory $\mathrm{T}$ cells can have a contributing role. ${ }^{23}$. Naturally occurring $\mathrm{CD} 25^{+} \mathrm{CD} 4^{+}$regulatory $\mathrm{T}$ cells engage in the maintenance of immunological self-tolerance and down-regulation of various immune responses ${ }^{24}$. These regulatory T cells specifically express FOXP3, a member of the forkhead/winged-helix family of transcriptional regulators, which encodes a transcriptionrepressor protein called scurfin 25 . Experimental data suggests that scurfin is implicated in regulation and suppression of T-cell activation ${ }^{26}$. Mutations in the FOXP3 gene have been identified in patients with a rare $\mathrm{X}$-linked recessive disorder of early childhood involving immune dysregulation, polyendocrinopathy, and enteropathy (IPEX syndrome) 27 . There is increasing evidence of similarities between AIE and IPEX syndrome $3,28,29$. IPEX syndrome tends to be lethal in male infants but now milder phenotypic variants have been described that may affect young adults 21,28 .

The pathogenic significance of GECA, including anti-enterocyte and ant-goblet cell antibodies is not entirely clear ${ }^{22}$. The detection of these autoantibodies remains observer-dependent and subjective, however, and no standardized test currently exists. Anti-enterocyte antibodies have not been reported in celiac disease, Crohn's disease or ulcerative colitis $12,30,31$, though they have been described in adult AIDS patients without digestive symptoms ${ }^{32}$. However, antigoblet cell antibodies have been reported in patients with chronic inflammatory bowel disease 33 , as well as in their asymptomatic first-degree relatives ${ }^{34}$. Intestinal biopsies have shown marked depletion of goblet cells in cases with positive anti-goblet cell antibodies 35,36 . In the current study, we did not observe any association between the clinical course, intestinal histology and the type of gut epithelial cell antibodies. The causative role of these antibodies 
have been questioned as they have been reported to appear after the onset of intestinal mucosal injury and disappear before the return to a normal mucosa 37 . Follow-up gut epithelial cell antibody testing was not done in our patients to corroborate these findings. Nevertheless, GECA offer a useful diagnostic tool in cases with protracted diarrhea and malabsorption.

Histologically both CVID and celiac disease are characterized by crypt hyperplastic villous atrophy 38,39 that grossly resembles AIE. However, CVID is characterized by absence of plasma cells in the intestinal biopsy specimens and on the other hand AIE may show an increase in the lamina propria plasma cells 38,40 . Similarly, in most cases AIE can be distinguished from celiac sprue by the lack of any significant IELs (defined as > 40 IEL per 100 epithelial cells) 41,42 . However, in the current study, only about half of the cases $(n=8)$ had histologic features characteristic of AIE, including minimal IELs, dense lamina propria inflammation, and increased crypt apoptotic bodies. The remaining seven cases either showed mixed AIE and sprue-like histology or classic sprue-like histology with none of the features of AIE. It is possible that these CD like mucosal changes represent wide spectrum of histological abnormalities that could also be observed in AIE. However, results form our series suggest that these two conditions can coexist. Five out of the seven patients with either sprue-like or mixed histologic picture also had elevated IgA tTG antibodies compared to normal celiac serology in all those with classic AIE-like histology. Two of these five patients fulfilled all the criteria for CD including, celiac associated serology, histology and HLA type, with the exception of a lack of response to the strict GFD. Both these patients could be categorized as having refractory sprue 43,44 , defined by the lack of response to GFD, with concurrent AIE as evident by the presence of gut epithelial antibodies. In both cases immunohistochemical studies showed normal IEL phenotype, primarily CD3+ CD4+ lymphocytes, most of which were also positive for $\beta \mathrm{F} 1$. None of the two patients had aberrant clonal T-cell receptor gene re-arrangement studies which can be seen in majority of cases with refractory sprue 45,46 . This highlights the fact that superimposed AIE should be considered, while excluding CD associated malignant complications 47,48 , in cases that otherwise fulfill criteria for glutenrefractory enteropathy ${ }^{4}$. Testing for GECA can help confirm the diagnosis of AIE. Early initiation of immunosuppressive therapy in all such cases can reduce AIE associated morbidity and malabsorptive complications.

Diarrhea associated with AIE tends to be unremitting without aggressive immunosuppression. Large doses of steroids are often necessary to control active disease and some patients do not respond to this conventional treatment. In the current study, over half $(60 \%)$ of the patients responded to steroid therapy. However, two thirds of these patients either became steroiddependent or refractory and required additional immunomodulators for maintenance of remission. Only one patient remained in long term clinical remission ( $>1$ year) on low dose prednisone (5mg/day) without any additional immunosuppression. Infliximab was used in two cases with a rapid and complete resolution of symptoms. A similar experience has been reported by others ${ }^{49}$. However, the uncontrolled nature of this study and relatively small sample size makes it difficult to compare different treatment regimens, and strong immunosuppressants like infliximab should only be used after thorough consideration of the risks versus benefits. Immunosuppressive medication can also induce cell mediated immune deficiency, which, when combined with humoral immune deficiency, can render patients highly susceptible to serious infections. Therefore, while instituting immunosuppressive treatment, we recommend a cautious approach and close monitoring especially in those with concomitant CVID.

\section{Conclusions}

Autoimmune enteropathy is a rare heterogeneous disease that should be considered in the differential diagnosis of malabsorption with small bowel villous atrophy. The presence of gut epithelial cell antibodies can help confirm the diagnosis of AIE. In most cases, 
immunosuppression is needed for the induction and maintenance of remission. Others are encouraged to report their findings to promote a better understanding of this rare entity.

\section{Acknowledgements}

JAM was supported by research grants DK 57982 and DK71003 from the National Institutes of Health, US Public Health Service

\section{References}

1. Walker-Smith JA, Unsworth DJ, Hutchins P, Phillips AD, Holborow EJ. Autoantibodies against gut epithelium in child with small-intestinal enteropathy. Lancet 1982;1:566-7. [PubMed: 6120421]

2. Unsworth DJ, Walker-Smith JA. Autoimmunity in diarrhoeal disease. J Pediatr Gastroenterol Nutr 41985:375-80.

3. Ruemmele FM, Brousse N, Goulet O. Autoimmune enteropathy: molecular concepts. Curr Opin Gastroenterol 2004;20:587-91. [PubMed: 15703687]

4. Biagi F, Corazza GR. Defining gluten refractory enteropathy. Eur J Gastroenterol Hepatol 2001;13:561-5. [PubMed: 11396537]

5. Bousvaros A, Leichtner AM, Book L, Shigeoka A, Bilodeau J, Semeao E, Ruchelli E, Mulberg AE. Treatment of pediatric autoimmune enteropathy with tacrolimus (FK506). Gastroenterology 1996;111:237-43. [PubMed: 8698205]

6. Daum S, Sahin E, Jansen A, Heine B, Riecken EO, Zeitz M, Schmidt W. Adult autoimmune enteropathy treated successfully with tacrolimus. Digestion 2003;68:86-90. [PubMed: 14581765]

7. Oliva-Hemker MM, Loeb DM, Abraham SC, Lederman HM. Remission of severe autoimmune enteropathy after treatment with high-dose cyclophosphamide. J Pediatr Gastroenterol Nutr 2003;36:639-43. [PubMed: 12717089]

8. Sanderson IR, Phillips AD, Spencer J, Walker-Smith JA. Response to autoimmune enteropathy to cyclosporin A therapy. Gut 1991;32:1421-5. [PubMed: 1752480]

9. Vanderhoof JA, Young RJ. Autoimmune enteropathy in a child: response to infliximab therapy. J Pediatr Gastroenterol Nutr 2002;34:312-6. [PubMed: 11964960]

10. Sykora J, Varvarovska J, Stozicky F, Kobr J, Pizingerova K, Schejbalova E, Tlaskalova H, Tuckova L, Sediva A, Janatkova I, Gutova V. [Autoimmune enteropathy with onset in early infancy: clinicomorphologic and immunologic manifestations]. Cas Lek Cesk 2002;141:646-50. [PubMed: 12515041]

11. Savage MO, Mirakian R, Wozniak ER, Jenkins HR, Malone M, Phillips AD, Milla PJ, Bottazzo GF, Harries JT. Specific autoantibodies to gut epithelium in two infants with severe protracted diarrhoea. J Pediatr Gastroenterol Nutr 1985;4:187-95. [PubMed: 3886868]

12. Mirakian R, Richardson A, Milla PJ, Walker-Smith JA, Unsworth J, Savage MO, Bottazzo GF. Protracted diarrhoea of infancy: evidence in support of an autoimmune variant. Br Med J (Clin Res Ed) 1986;293:1132-6.

13. Hill SM, Milla PJ, Bottazzo GF, Mirakian R. Autoimmune enteropathy and colitis: is there a generalised autoimmune gut disorder? Gut 1991;32:36-42. [PubMed: 1991636]

14. Leon F, Olivencia P, Rodriguez-Pena R, Sanchez L, Redondo C, Alvarez I, Moreira V, Roy G. Clinical and immunological features of adult-onset generalized autoimmune gut disorder. Am J Gastroenterol 2004;99:1563-71. [PubMed: 15307878]

15. Corazza GR, Biagi F, Volta U, Andreani ML, De Franceschi L, Gasbarrini G. Autoimmune enteropathy and villous atrophy in adults. Lancet 1997;350:106-9. [PubMed: 9228963]

16. McCune CA, Hughes S, Unsworth DJ. Thymoma, autoimmunity and fatal immunodeficiency. Qjm 2000;93:559-60. [PubMed: 10924541]

17. Casis B, Fernandez-Vazquez I, Barnardos E, Saiz A, Ballestin C, Morillas JD, Colina F, Solis-Herruzo JA. Autoimmune enteropathy in an adult with autoimmune multisystemic involvement. Scand J Gastroenterol 2002;37:1012-6. [PubMed: 12374224]

18. Carroccio A, Volta U, Di Prima L, Petrolini N, Florena AM, Averna MR, Montalto G, Notarbartolo A. Autoimmune enteropathy and colitis in an adult patient. Dig Dis Sci 2003;48:1600-6. [PubMed: 12924654] 
19. Mais DD, Mulhall BP, Adolphson KR, Yamamoto K. Thymoma-associated autoimmune enteropathy. A report of two cases Am J Clin Pathol 1999;112:810-5.

20. Mitomi H, Tanabe S, Igarashi M, Katsumata T, Arai N, Kikuchi S, Kiyohashi A, Okayasu I. Autoimmune enteropathy with severe atrophic gastritis and colitis in an adult: proposal of a generalized autoimmune disorder of the alimentary tract. Scand J Gastroenterol 1998;33:716-20. [PubMed: 9712235]

21. Al Khalidi H, Kandel G, Streutker CJ. Enteropathy with loss of enteroendocrine and paneth cells in a patient with immune dysregulation: a case of adult autoimmune enteropathy. Hum Pathol 2006;37:373-6. [PubMed: 16613334]

22. Russo PAF. Autoimmune enteropathy - A review. Clinical and Applied Immunology Reviews 2002;2 (14):203-216.

23. Sakaguchi S. Naturally arising Foxp3-expressing CD25+CD4+ regulatory T cells in immunological tolerance to self and non-self. Nat Immunol 2005;6:345-52. [PubMed: 15785760]

24. Yagi H, Nomura T, Nakamura K, Yamazaki S, Kitawaki T, Hori S, Maeda M, Onodera M, Uchiyama T, Fujii S, Sakaguchi S. Crucial role of FOXP3 in the development and function of human CD25 +CD4+ regulatory T cells. Int Immunol 2004;16:1643-56. [PubMed: 15466453]

25. Sakaguchi S. The origin of FOXP3-expressing CD4+ regulatory T cells: thymus or periphery. J Clin Invest 2003;112:1310-2. [PubMed: 14597756]

26. Schubert LA, Jeffery E, Zhang Y, Ramsdell F, Ziegler SF. Scurfin (FOXP3) acts as a repressor of transcription and regulates T cell activation. J Biol Chem 2001;276:37672-9. [PubMed: 11483607]

27. Brunkow ME, Jeffery EW, Hjerrild KA, Paeper B, Clark LB, Yasayko SA, Wilkinson JE, Galas D, Ziegler SF, Ramsdell F. Disruption of a new forkhead/winged-helix protein, scurfin, results in the fatal lymphoproliferative disorder of the scurfy mouse. Nat Genet 2001;27:68-73. [PubMed: 11138001]

28. De Benedetti F, Insalaco A, Diamanti A, Cortis E, Muratori F, Lamioni A, Carsetti R, Cusano R, De Vito R, Perroni L, Gambarara M, Castro M, Bottazzo GF, Ugazio AG. Mechanistic Associations of a Mild Phenotype of Immunodysregulation, Polyendocrinopathy, Enteropathy, X-Linked Syndrome. Clin Gastroenterol Hepatol. 2006

29. Wildin RS, Freitas A. IPEX and FOXP3: clinical and research perspectives. J Autoimmun 2005;25 (Suppl):56-62. [PubMed: 16243487]

30. Lachaux A. [Autoimmune enteropathy]. Arch Pediatr 1996;3:261-6. [PubMed: 8785566]

31. Russo PA, Brochu P, Seidman EG, Roy CC. Autoimmune enteropathy. Pediatr Dev Pathol 1999;2:6571. [PubMed: 9841709]

32. Martin-Villa JM, Camblor S, Costa R, Arnaiz-Villena A. Gut epithelial cell autoantibodies in AIDS pathogenesis. Lancet 1993;342:380. [PubMed: 8101628]

33. Hibi T, Ohara M, Kobayashi K, Brown WR, Toda K, Takaishi H, Hosoda Y, Hayashi A, Iwao Y, Watanabe M, et al. Enzyme linked immunosorbent assay (ELISA) and immunoprecipitation studies on anti-goblet cell antibody using a mucin producing cell line in patients with inflammatory bowel disease. Gut 1994;35:224-30. [PubMed: 8307474]

34. Folwaczny C, Noehl N, Tschop K, Endres SP, Heldwein W, Loeschke K, Fricke H. Goblet cell autoantibodies in patients with inflammatory bowel disease and their first-degree relatives. Gastroenterology 1997;113:101-6. [PubMed: 9207267]

35. Rogahn D, Smith CP, Thomas A. Autoimmune enteropathy with goblet-cell antibodies. J R Soc Med 1999;92:311-2. [PubMed: 10472291]

36. Moore L, Xu X, Davidson G, Moore D, Carli M, Ferrante A. Autoimmune enteropathy with antigoblet cell antibodies. Hum Pathol 1995;26:1162-8. [PubMed: 7557954]

37. Unsworth J, Hutchins P, Mitchell J, Phillips A, Hindocha P, Holborow J, Walker-Smith J. Flat small intestinal mucosa and autoantibodies against the gut epithelium. J Pediatr Gastroenterol Nutr 1982;1:503-13. [PubMed: 7186065]

38. Kalha I, Sellin JH. Common variable immunodeficiency and the gastrointestinal tract. Curr Gastroenterol Rep 2004;6:377-83. [PubMed: 15341713]

39. Ciccocioppo R, D’Alo S, Di Sabatino A, Parroni R, Rossi M, Doglioni C, Cifone MG, Corazza GR. Mechanisms of villous atrophy in autoimmune enteropathy and coeliac disease. Clin Exp Immunol 2002;128:88-93. [PubMed: 11982595] 
40. Washington K, Stenzel TT, Buckley RH, Gottfried MR. Gastrointestinal pathology in patients with common variable immunodeficiency and X-linked agammaglobulinemia. Am J Surg Pathol 1996;20:1240-52. [PubMed: 8827031]

41. Veress B, Franzen L, Bodin L, Borch K. Duodenal intraepithelial lymphocyte-count revisited. Scand J Gastroenterol 2004;39:138-44. [PubMed: 15000275]

42. Cuenod B, Brousse N, Goulet O, De Potter S, Mougenot JF, Ricour C, Guy-Grand D, Cerf-Bensussan N. Classification of intractable diarrhea in infancy using clinical and immunohistological criteria. Gastroenterology 1990;99:1037-43. [PubMed: 2203660]

43. Culliford AN, Green PH. Refractory sprue. Curr Gastroenterol Rep 2003;5:373-8. [PubMed: 12959717]

44. Green PH, Jabri B. Coeliac disease. Lancet 2003;362:383-91. [PubMed: 12907013]

45. Cellier C, Delabesse E, Helmer C, Patey N, Matuchansky C, Jabri B, Macintyre E, Cerf-Bensussan N, Brousse N. Refractory sprue, coeliac disease, and enteropathy-associated T-cell lymphoma. French Coeliac Disease Study Group. Lancet 2000;356:203-8. [PubMed: 10963198]

46. Patey-Mariaud De Serre N, Cellier C, Jabri B, Delabesse E, Verkarre V, Roche B, Lavergne A, Briere J, Mauvieux L, Leborgne M, Barbier JP, Modigliani R, Matuchansky C, MacIntyre E, CerfBensussan N, Brousse N. Distinction between coeliac disease and refractory sprue: a simple immunohistochemical method. Histopathology 2000;37:70-7. [PubMed: 10931221]

47. Wright DH. The major complications of coeliac disease. Baillieres Clin Gastroenterol 1995;9:35169. [PubMed: 7549031]

48. Brousse N, Meijer JW. Malignant complications of coeliac disease. Best Pract Res Clin Gastroenterol 2005;19:401-12. [PubMed: 15925845]

49. Elwing JE, Clouse RE. Adult-onset autoimmune enteropathy in the setting of thymoma successfully treated with infliximab. Dig Dis Sci 2005;50:928-32. [PubMed: 15906770]

\section{Abbreviations used in this paper}

\section{AIE}

autoimmune enteropathy

GECA

gut epithelial cell antibodies

CD

Celiac disease

$\mathbf{A E}$

anti-enterocyte

AG

anti-goblet

tTG

tissue transglutaminase 


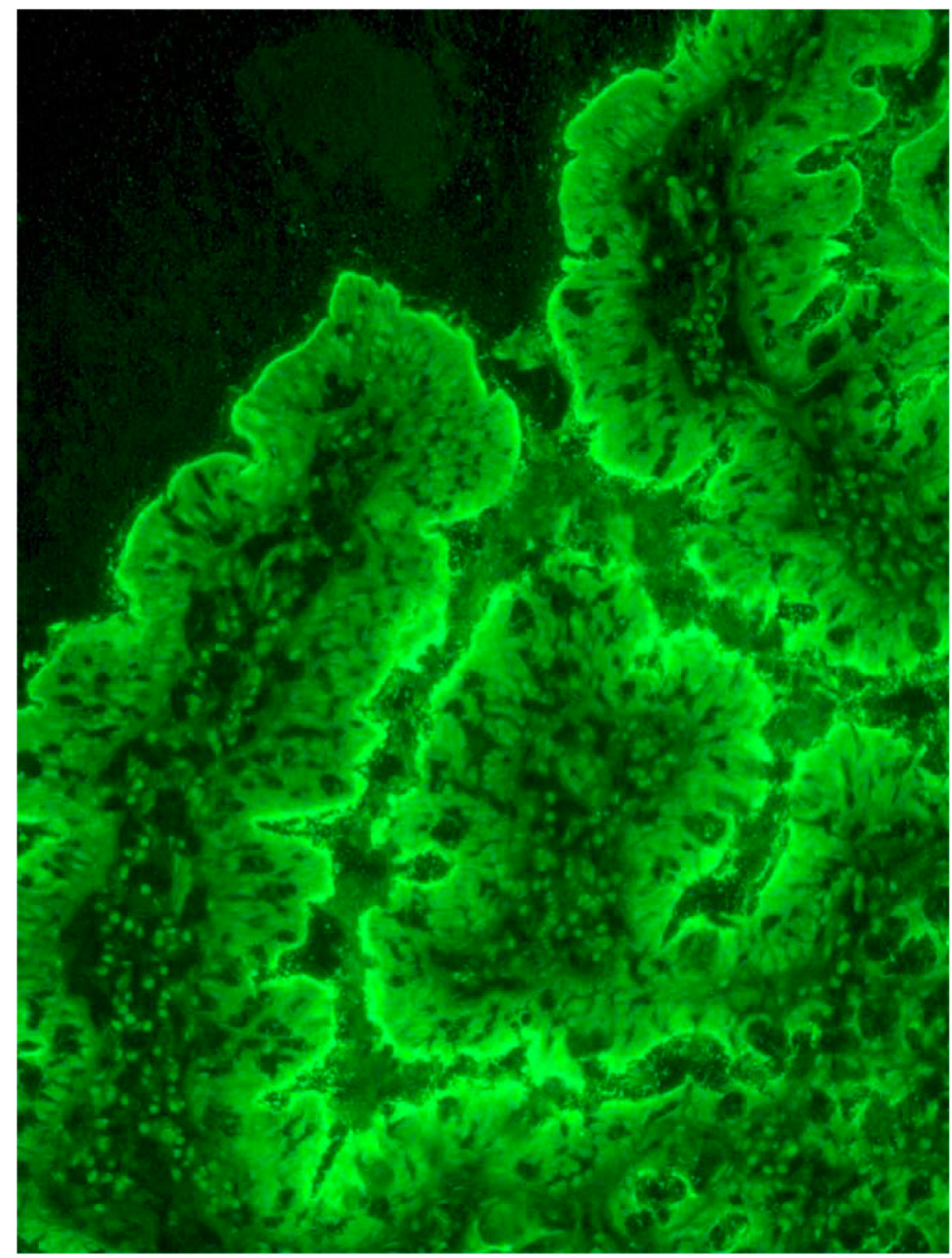

Figure 1. Anti-enterocyte antibodies

Indirect immunofluorescence using the patient's serum on frozen section of normal human small bowel shows a linear fluorescence pattern along the brush border of the enterocytes $(x$ $300)$. 


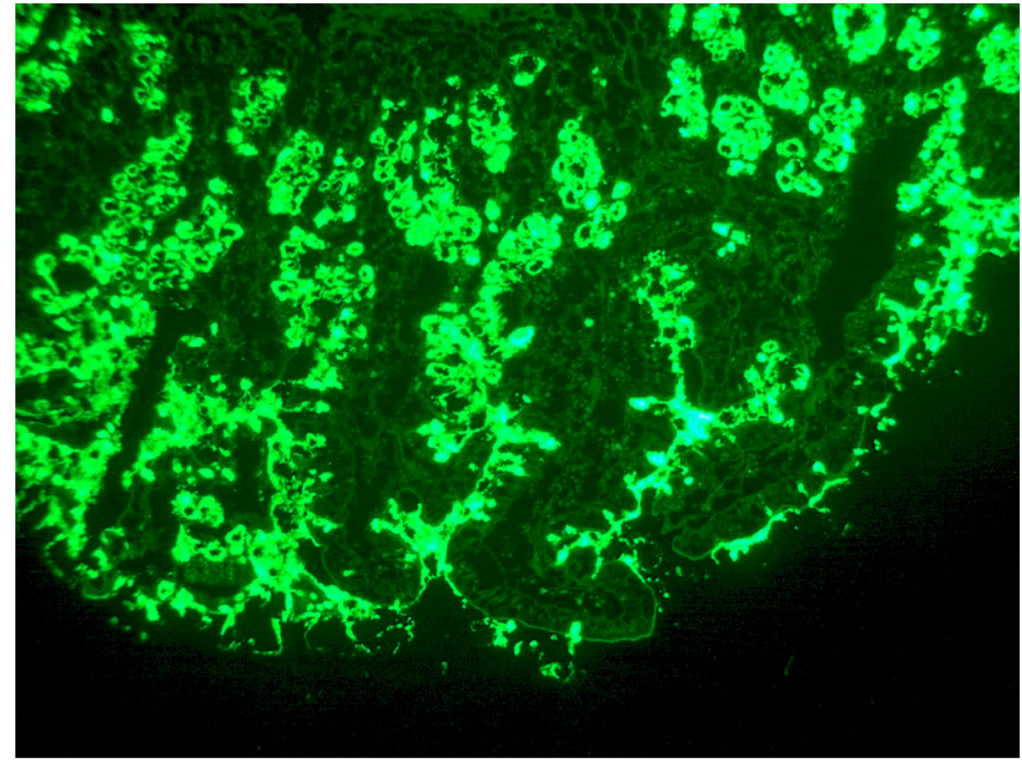

Figure 2. Anti-goblet cell antibodies

Immunofluorescence staining in the goblet cells mucus, sparing the enterocytes $(\times 100)$ 


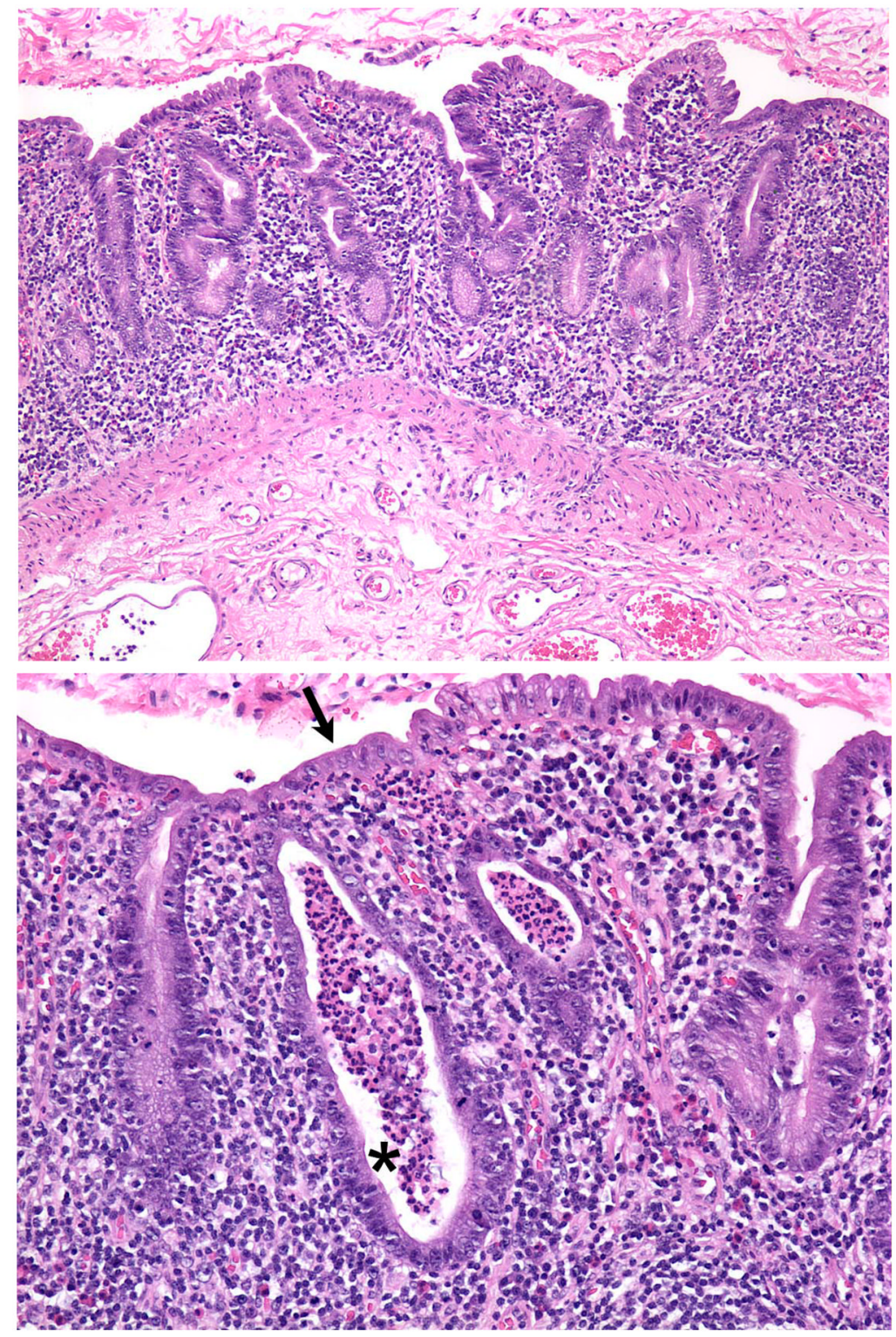

Figure 3.

Histopathologic findings in a patient with autoimmune enteritis associated with anti-goblet cell antibodies. (A) Low-power view of the jejunum shows near-total villous atrophy and dense lymphoplasmacellular inflammation in the lamina propria. (B) At higher power, there is surface epithelial injury with disruption of the brush border (arrow) and intense neutrophilic inflammation including crypt abscesses (asterisk). There is no abnormal lymphocytosis in the surface epithelium. 

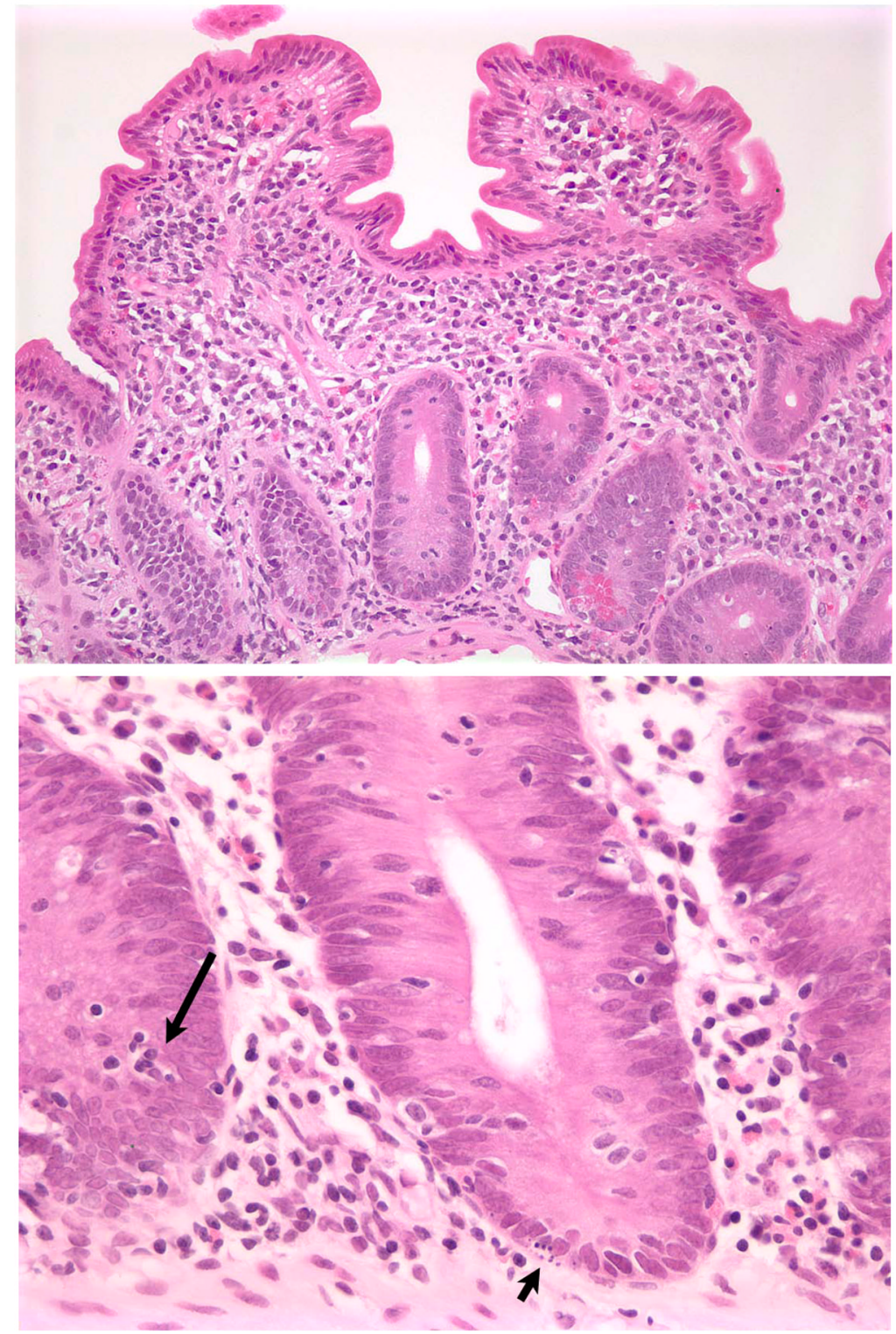


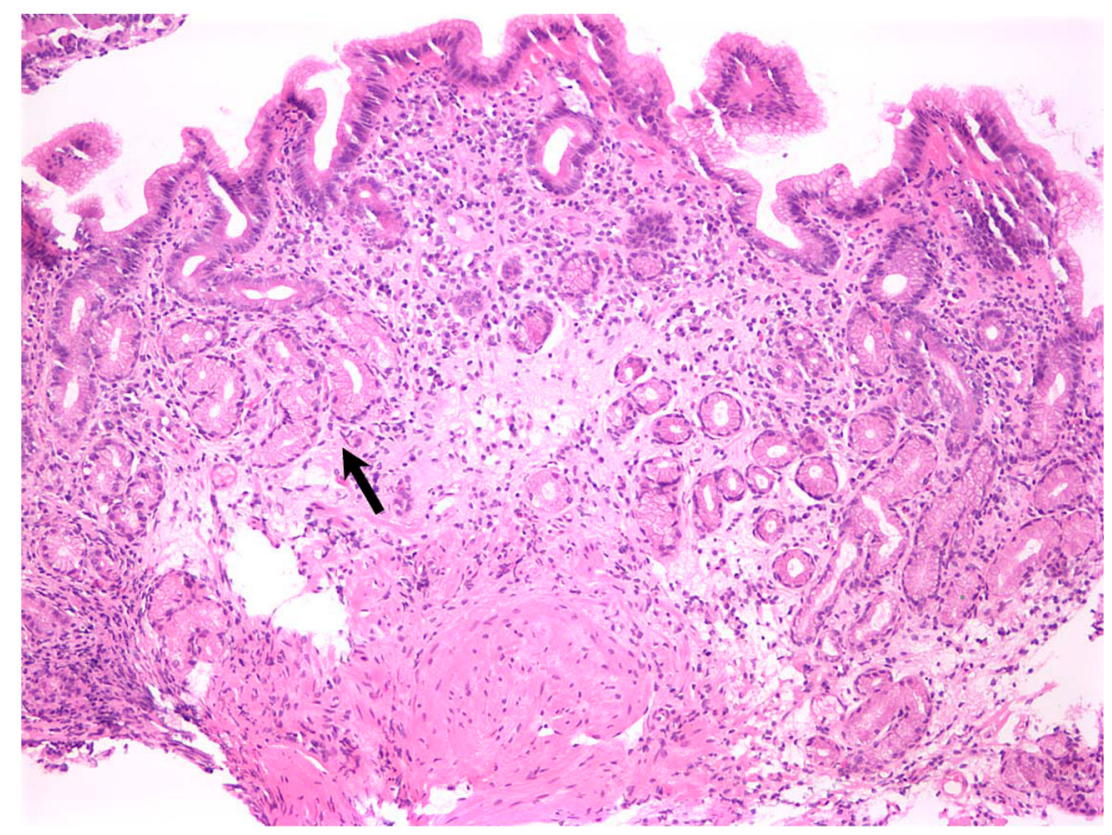

Figure 4.

Histopathologic findings in a patient with anti-goblet cell antibodies and pan-gastrointestinal autoimmune disease. (A) Duodenal biopsy demonstrates moderate villous blunting and absence of goblet cells; there is no abnormal surface lymphocytosis. (B) Colonic biopsy with absent goblet cells, mild lymphocytosis in the deep crypt epithelium (arrow), and crypt apoptosis (arrowhead). (C) Gastric biopsy taken from the fundus demonstrates features of autoimmune atrophic gastritis, with complete absence of oxyntic glands and partial replacement by pseudo-pyloric metaplasia (arrow). 


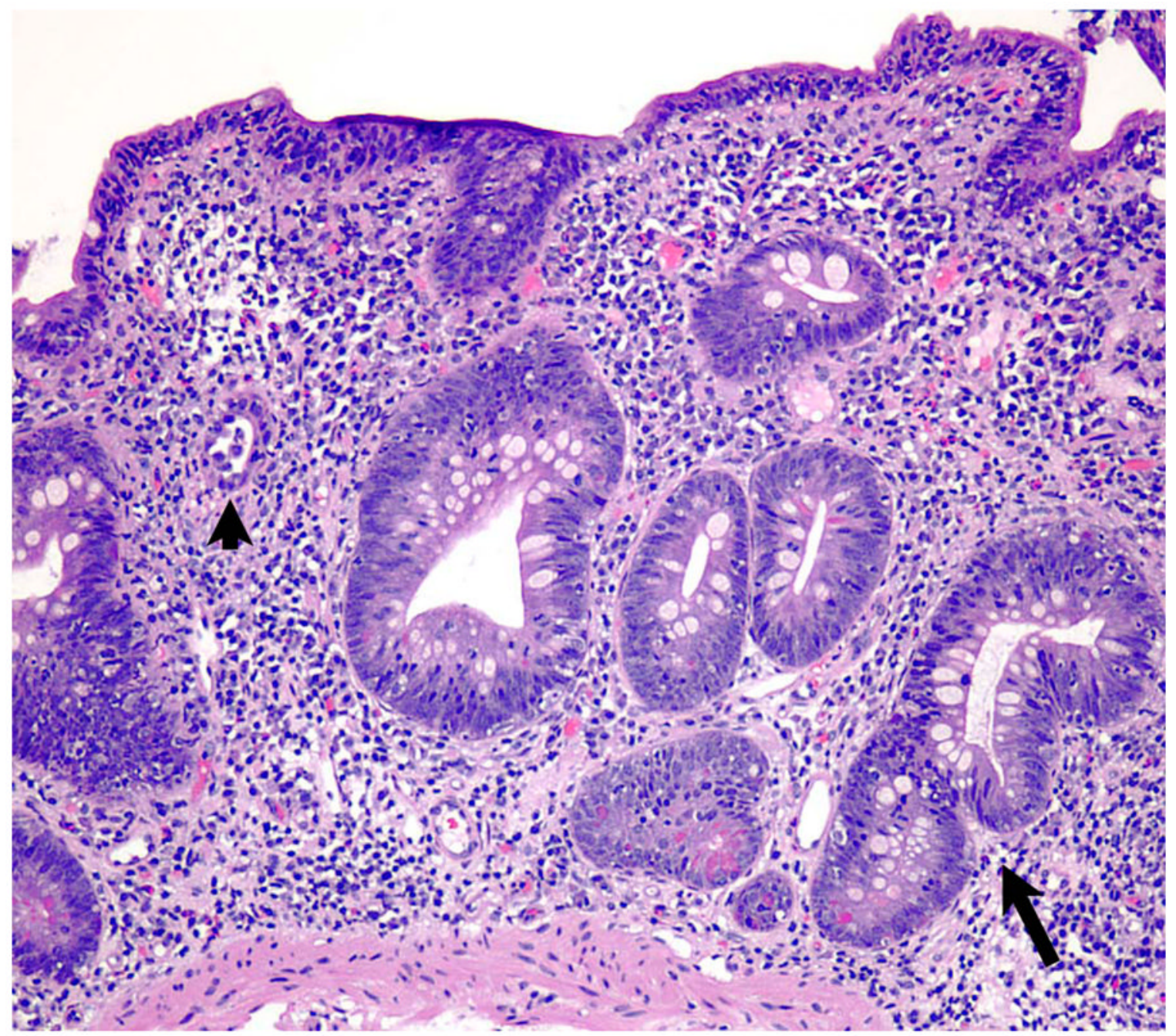




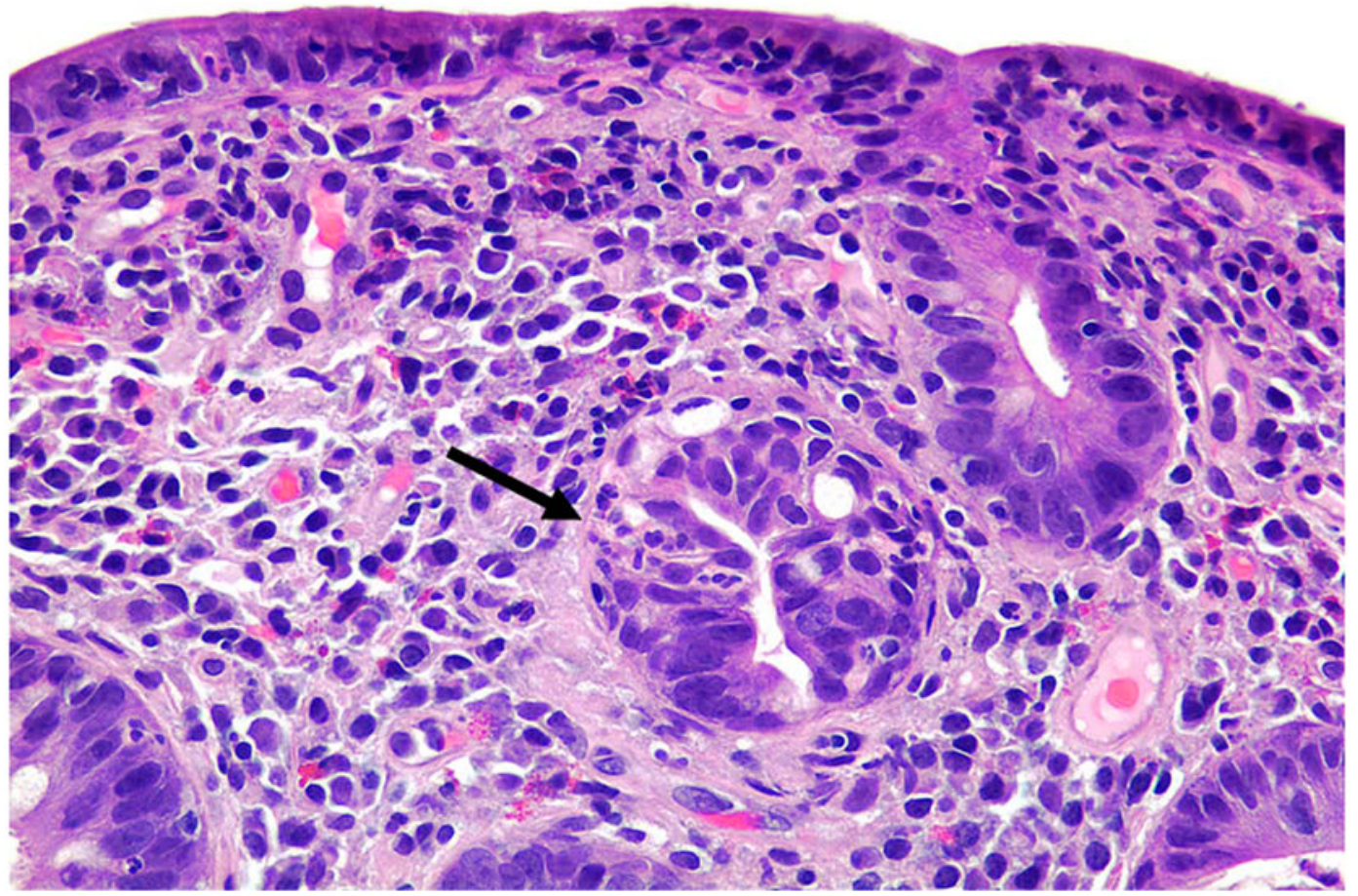

Figure 5.

Histopathologic features in overlap between autoimmune enteropathy and celiac disease. (A) The duodenal biopsy shows near-total villous blunting with crypt architectural distortion including crypt branching (arrow) and crypt destruction (arrowhead), both unusual features of "pure" celiac disease. (B) At high power, there is intense surface intraepithelial lymphocytosis typical for celiac disease, but there is also neutrophilic cryptitis (arrow) and scattered neutrophils in the surface epithelium. This patient had positive anti-enterocyte antibodies, HLA type DQ2, and a weakly positive IgA tissue-transglutaminase antibody. 
Table 1

Summary of Clinical Characteristics of Study Population

\begin{tabular}{lc}
\hline Patient Characteristics & Data (N=15) \\
\hline Median age at diagnosis in yrs. (IQR) & $55(42-67)$ \\
Median duration of symptom in yrs. prior to AIE diagnosis (IQR) & $1.5(1-4.5)$ \\
Male (\%) & $8(53)$ \\
Median follow-up in yrs. (IQR) & $2(1-4.8)$ \\
GECA (\%) (Table 3) & $13(87)$ \\
Other autoantibodies (Table 2) & $10(67)$ \\
tTG positive (\%) & $5(33)$ \\
Associated autoimmune disorders (\%) (Table 2) & $13(87)$ \\
\hline
\end{tabular}

IQR: Interquartile range $\left(25 \mathrm{th}-75^{\text {th }}\right.$ percentile $)$, AIE: Autoimmune enteropathy

GECA: gut epithelial cell antibodies (anti-enterocyte antibodies and/or anti-goblet cell antibodies).

tTG: Tissue transglutaminase antibodies 
Akram et al.

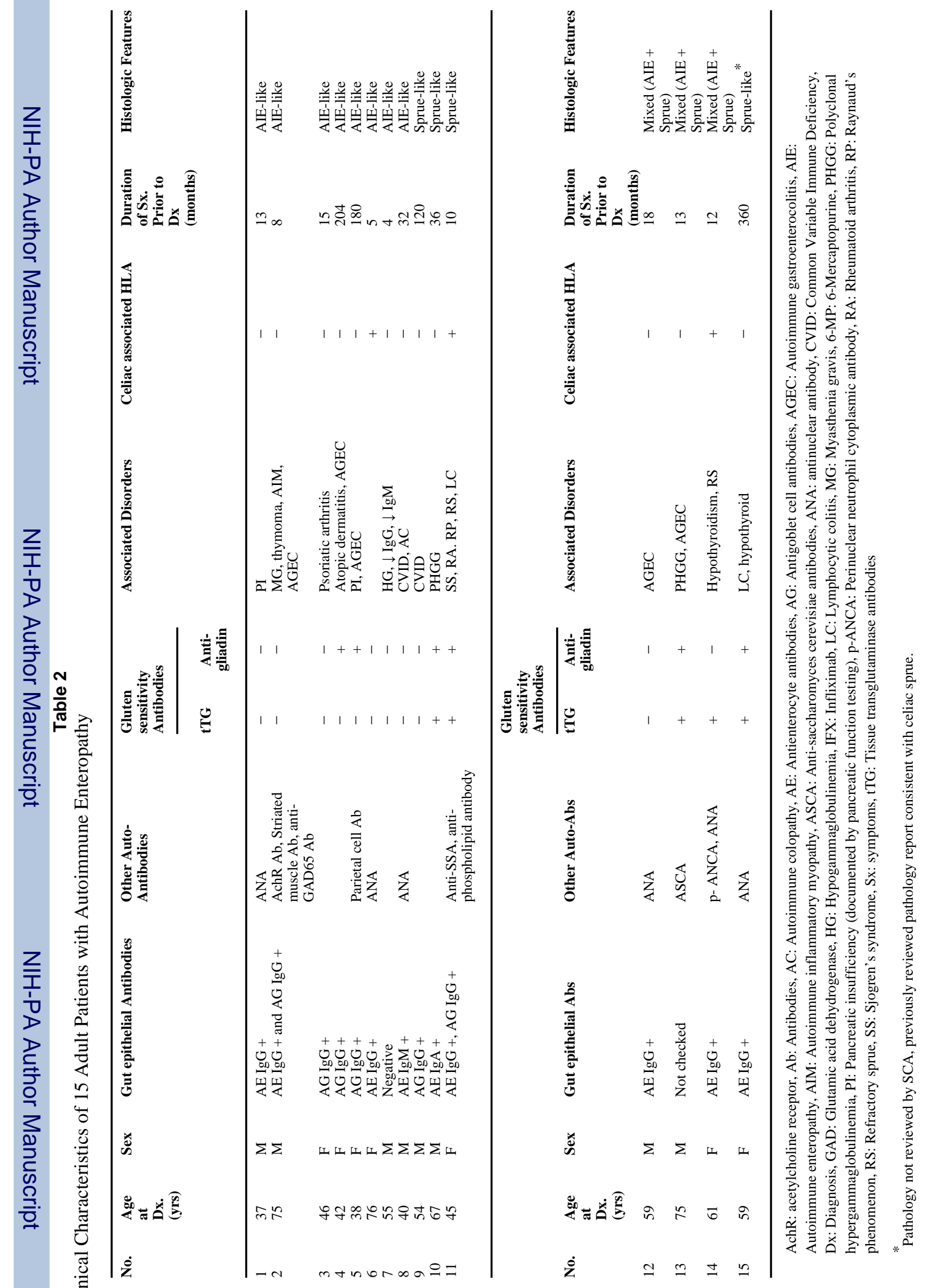

Clin Gastroenterol Hepatol. Author manuscript; available in PMC 2008 November 1. 


\section{Gut Epithelial Cell Autoantibodies (GECA)}

\begin{tabular}{ll}
\hline GECA & No. (\%) \\
\hline Anti-enterocyte IgG antibodies & $5(33)$ \\
Anti-enterocyte IgM antibodies & $1(7)$ \\
Anti-enterocyte IgA antibodies & $1(7)$ \\
Anti-goblet cell IgG antibodies & $4(27)$ \\
Anti-enterocyte IgG plus anti-goblet cell IgG antibodies & $2(13)$ \\
\hline Total & $13(87)$ \\
\hline
\end{tabular}

Anti-goblet cell IgG antibodie

$13(87)$

Table 3 


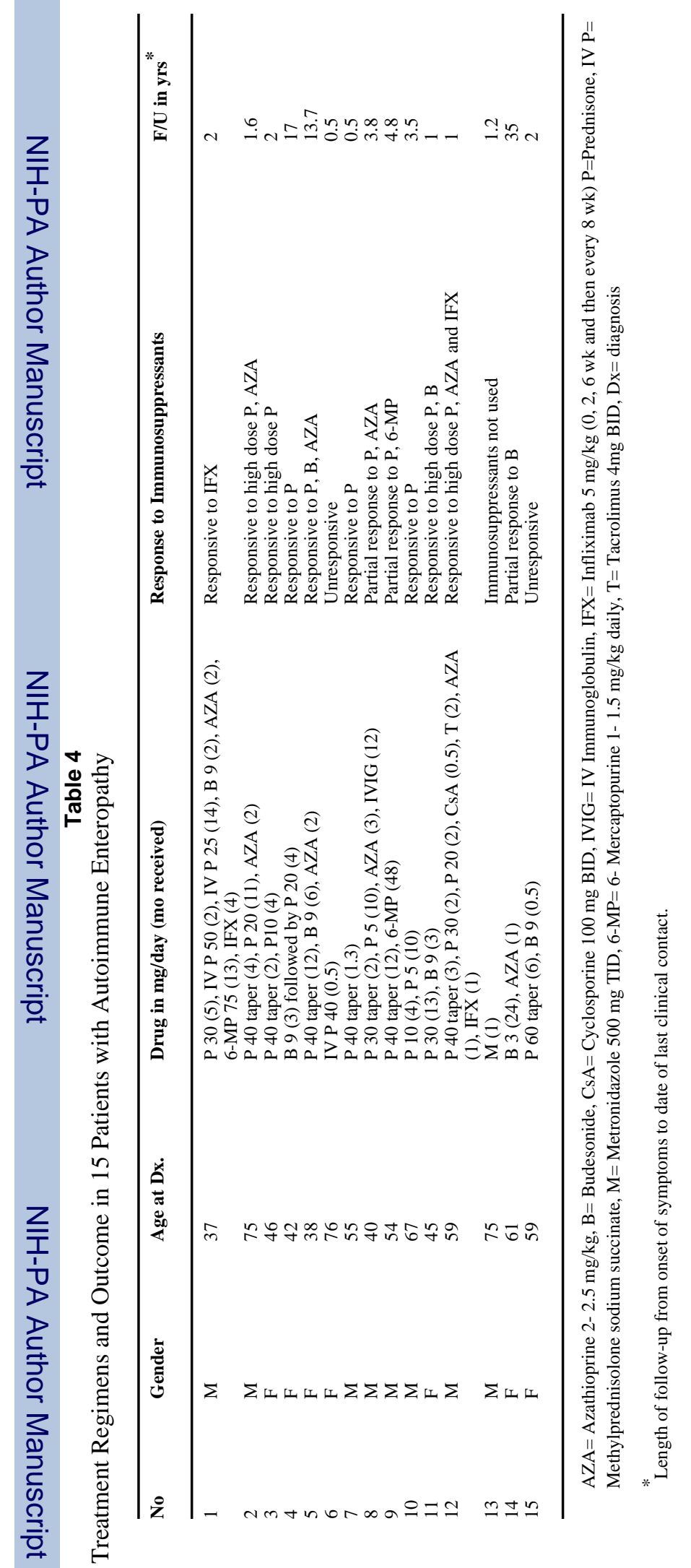

Clin Gastroenterol Hepatol. Author manuscript; available in PMC 2008 November 1. 


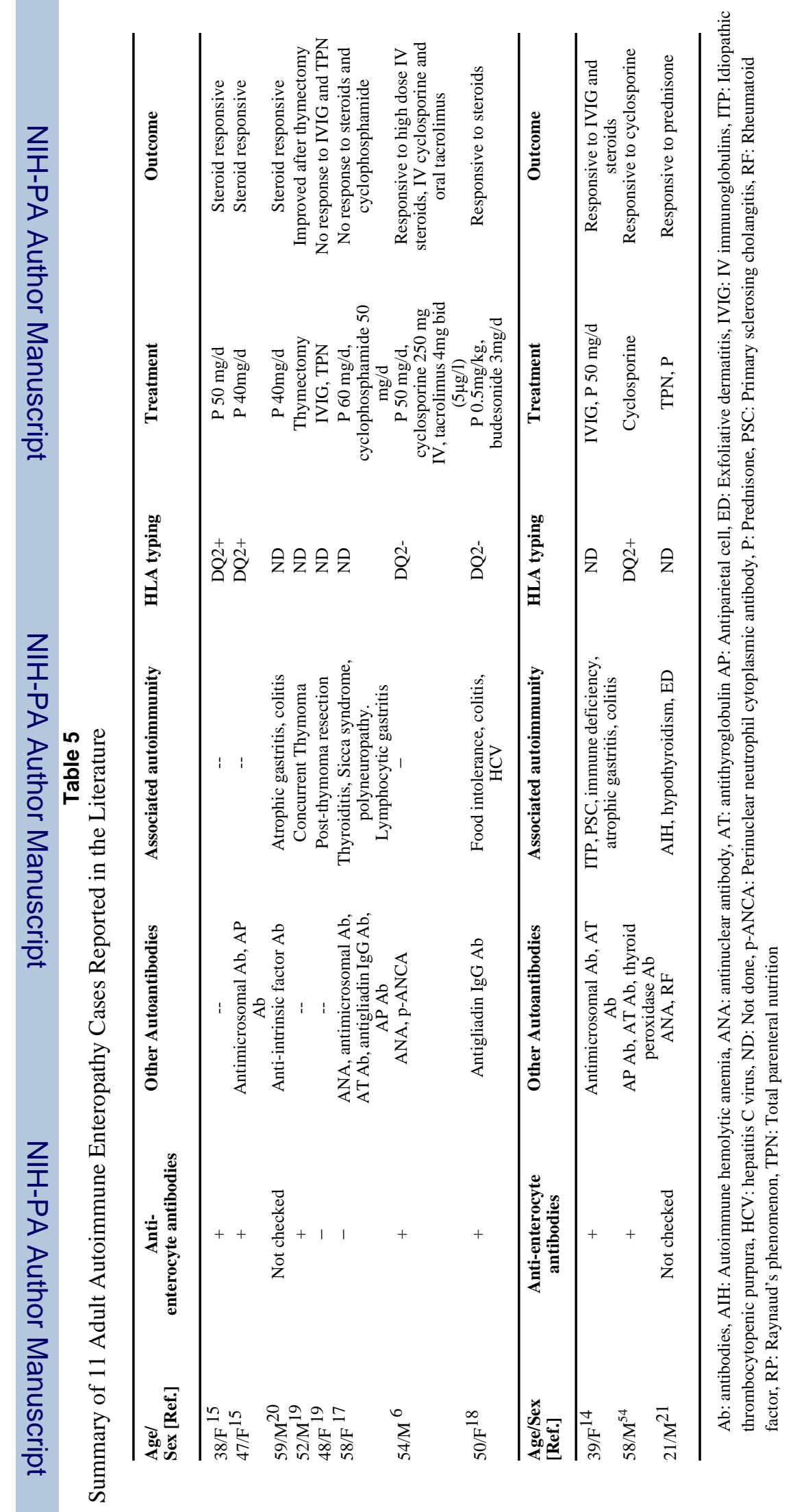


Table 6

Proposed Diagnostic Criteria for Adult Autoimmune Enteropathy

Major Criteria:

1 Adult-onset chronic diarrhea (> 6 weeks duration)

2 Malabsorption

3 Specific small bowel histology;

a. Partial/complete villous blunting

b. Deep crypt lymphocytosis

c. Increased crypt apoptotic bodies

d. Minimal intra-epithelial lymphocytosis

4 Exclusion of other causes of villous atrophy including celiac disease, refractory sprue and intestinal lymphoma.

5 Anti-enterocyte and/or anti-goblet cell antibodies

Criteria 1-4 are required for a definite diagnosis of AIE. Presence of anti-enterocyte and/or anti-goblet cell antibodies is an important diagnostic support but their absence does not exclude the diagnosis of AIE. 